Chirurgia (2020) 115: 767-774

No. 6, November - December

Copyright@ Celsius

http://dx.doi.org/10.21614/chirurgia.115.6.767

\title{
Effect of Fibrin Sealant on Seroma Formation Post-Incisional Hernia Repair
}

\author{
Beatrice D’Orazio,", Fausto Famà ${ }^{3}$, Carmelo Sciumé1, Bianca Cudia', Giovanni Corbo ${ }^{1,2}$, Gloria Terranova ${ }^{1,2}$, \\ Dario Cali ${ }^{1,2}$, Sebastiano Bonventre', Gaetano Di Vita ${ }^{1}$, Girolamo Geraci'
}

\author{
${ }^{1}$ General Surgery Unit - Department of Surgical, Oncological and Stomatological Sciences, University of Palermo, Italy \\ ${ }^{2}$ Postgraduate Medical School in General Surgery, University of Palermo, Palermo, Italy \\ 'Department of Human Pathology in Adulthood and Childhood "G. Barresi" \\ University Hospital "G. Martino" of Messina
}

${ }^{*}$ Corresponding author:

Gaetano Di Vita, MD

General Surgery Unit

Department of Surgical, Oncological

and Stomatological Sciences,

University of Palermo. Via Liborio

Giuffrè, 5 - 90127 Palermo, Italy

E-mail: divitagaetano@libero.it
Received: 21.07 .2020

Accepted: 09.09.2020

\section{Rezumat}

Efectul sigilantului cu fibrină asupra formării de seroame după herniplastii de hernie incizională

Context: Formarea de seroame după hernioplastii de hernie incizională este o complicație comună. Studiul nostru are obiectivul de a compara rezultatele cu sau fără instilarea prin atomizare de adeziv cu fibrină ale hernioplastiilor de hernie incizională cu poziționare sublay.

Metode: În studiu au fost înrolați cincizeci de pacienți de hernioplastie de hernie incizională. Drenurile de aspirație au fost introduse, la toți pacienții, în spațiul subcutanat. La unul din grupurile de pacienți (FG) s-au instilat $4 \mathrm{ml}$ de adeziv cu fibrină în spațiul subcutanat. Pacienții din grupul de control (C) nu au beneficiat de nicio măsură preventivă. S-au colectat secrețiile plăgilor în ziua 1 postoperator (POD 1) şi, ulterior, zilnic până la scoaterea drenului. Toți pacienții au fost monitorizați ecografic în POD 15, 20, 40, 60.

Rezultate: Secreția drenată, deşi substanțial mai puternică în grupul C $(p<0,01)$, comparativ cu grupul FG, a scăzut după POD 1 în ambele grupuri. Drenul a fost scos în POD 5 la 80\% din pacienții din grupul FG şi la $36 \%$ din pacienții din grupul $\mathrm{C}(\mathrm{p}<0,01)$. Nu s-au identificat complicații de natură infecțioasă sau hemoragică. Durata medie a spitalizării a fost de $5,5 \pm 2$ zile pentru grupul FG, față de $7,1 \pm 1,5$ zile pentru grupul $C(p<0.01)$. Ecografic, s-a identificat formare de seroame similară în ambele grupuri.

Concluzii: Instilarea prin atomizare de adeziv cu fibrină în cadrul 
hernioplastiei de hernie incizională reduce cantitativ secrețile drenate şi durata spitalizării, fără a creşterea numărului de complicații de natură chirurgicală. Totuşi, nu s-a redus substanțial formarea de seroame.

Cuvinte cheie: serom, adeziv cu fibrină, hernie incizională, hernioplastie chirurgicală

\begin{abstract}
Background:Development of seroma after incisional hernia repair is a common complication. Our study aims to compare the outcomes of sublay incisional hernia repairs with or without spray instillation of fibrin glue.

Methods: We enrolled fifty patients undergoing incisional hernia repair. In all patients a suction drain was placed in the subcutaneous space. In one group (FG) $4 \mathrm{ml}$ fibrin glue was instilled in the subcutaneous space. In the control group (C) patients did not receive any prevention measure. Wounds fluids were collected on post-operative day 1 (POD) and once daily until drain removal. All patients were followed up by ultrasound on POD 15, 20, 40, 60.

Results: Drain fluid production, even if in significantly greater amount in the $\mathrm{C}$ group $(\mathrm{p}<0.01)$ as compared with the FG group, decreased after POD 1 in both groups. Drain was removed on POD- 5 in $80 \%$ of $\mathrm{FG}$ patients and in $36 \%$ of $\mathrm{C}$ patients $(\mathrm{p}<0.01)$. No infective or bleeding complications were detected. In group FG average hospital stay was of $5.5 \pm 2$ days versus $7.1 \pm 1.5$ days in group $\mathrm{C}$ $(\mathrm{p}<0.01)$. At ultrasounds examination, seroma development was similar among two groups.

Conclusions: Spray instillation of fibrin glue during the surgical repair reduces amount of drained fluid and hospital stay without increasing surgical complications. However, seroma occurrence was not significantly reduced.
\end{abstract}

Key words: seroma, fibrin sealant, incisional hernia, surgical hernia repair

\section{Introduction}

Incisional hernia occurs between 11 and 20\%, of laparotomies. Hernias are associated with reduced quality of life and high economic costs $(1,2)$. Recurrence after conventional suture repair is ranges from $12 \%$ to $54 \%$. The treatment of incisional hernias associated to lower rate of hernia recurrence should be mesh repair, performed by open and laparoscopic methods $(3,4)$. Wound complications are the commonest problem in incisional hernia repair using mesh and the formation of seroma is the most frequent problem. The rate of seroma occurence after surgical incisional hernia repair with mesh varies between $2 \%$ and $30 \%$ (5). This wide variability must be attributed to the definition and evaluation criteria employed. The genesis of seroma is unknown. It is often asymptomatic and it does not need any treatment because it usually will reabsorbed. In $35 \%$ of cases percutaneous aspiration, drainage or reoperation may be necessary due to persistent pain, discomfort, or presence of infection (6).

Different techniques have been used to reduce the incidence of seroma such as use of drains, quilting sutures between subcutaneous and fascia, use of harmonic scalpel for tissue dissection, talc, etc. Despite prior attempts to reduce the risk of post-operative seromas, no single technique has been shown to eliminate the risk. Recently, there is a growing interest of potential application of fibrin sealant for reducing post-operative seroma formation, but supporting data remain sparse $(7,8)$.

The objective of this study was to evaluate if application of high-concentration heterologous fibrin sealant between subcutaneous 
tissue and the sheath of the external oblique muscle after open prosthetic incisional hernia repair with sublay technique, could reduce the amount of drained liquid and decrease the incidence of post-operative seroma in this space. Secondary endpoint was to reduce the onset of other complications in the surgical site (such as surgical site infection).

\section{Methods}

Fifty patients undergoing surgical incisional hernia repair were included in this study casecontrol study. All of the patients were affected by midline incisional hernia with hernial holes of maximum diameter raging $3,5-5 \mathrm{~cm}$, located at periumbilical region. We excluded patients older than 70 years-old, with co-morbidities like diabetes, hepatic cirrhosis, renal or heart failure, with infection or potentially contaminated surgical field, patients with recurrent hernia or with necessity of concomitant abdominal surgery. The data of the patients were collected prospectively.

All patients preoperatively received intravenous dose of $2 \mathrm{gr}$ ceftadizime that was continued twice a day for three post-operative days along with low molecular weight heparin prophylxis.

All participants gave a written informed consent.

\section{Surgical Procedure}

The surgical procedure starts with excision of the skin scar. The skin was separated from the surrounding tissue and wide undermining of the subcutaneous was done up to semilunar line. The length and width of the resulting dead space after subcutaneous dissection was measured. The escess hernial sac has been preserved and the medial edge of each rectus muscle was identified by palpation, and extreme medial edge of each rectus sheath was incised along its length to enter in the submuscular space.

This relatively bloodless plane could be developed easily to the lateral edges of the rectus muscle on each side. Dissection was stopped when an overlap of 5-6 $\mathrm{cm}$ to both lateral sides was reached. The vascularnervous bundle of rectal muscle was identified to avoid its damage during the preparation (9).

The posterior sheath of right rectal muscle was secured to the posterior sheath of the left one with a continuous suture. High-density polypropylene mesh was placed between posterior sheath of rectal muscle and rectal muscle itself. The size of the mesh was $10 \times 10$ $\mathrm{cm}$. Mesh was secured with some 3-0 polypropylene stitches placed at the limits of dissection. A closed suction drain was placed over the mesh. In all cases both rectal muscles were closed to the median line and the external oblique muscle's sheath was secured with separated stitches. Relaxing incision in the anterior rectal sheath were performed in all cases. Another closed suction drain was placed between the subcutaneous fat and oblique external sheath.

Patients have been allocated into two group, both involving 25 units. In the control group (Group C), consisting of patients who have already been subjected to previous studies, no prevention has been applied (10-13); in the second group (group FG) 25 consecutive patients undergoing surgery from January 2016 until January 2018 were included and treated with the administration of $4 \mathrm{ml}$ Fibrin glue with spray applicator in the subcutaneous space. Tisseel or Tissucol (Baxter ${ }^{\circledR}$ ) was used, which has among its components bovine aprotinin $3000 \mathrm{KIU} / \mathrm{ml}$ and high concentration of thrombin (500 IU/ml). Fibrin glue was applied both to the surface of the tissue and fascia. Drainage fluids were cultured only if infection was suspected (notably wound edema, erythema, or serosanguinous discharge), although this was not required in any patient included in the study. Body temperature was monitored by axillary temperature measurement.

Postoperative pain was assessed by the patient on mobilization by means of a visual analogue scale ranging from 0 (no pain) to 10 (worst pain imaginable) at 24 and 48 hours and on postoperative days (POD) 7, 15 and 30 . Patients discharged before these times were requested to record pain at home. An analgesic 
therapy (oral tramadol hydrochloride) was administered on demand.

\section{Wound Fluid Samples and Assays}

Surgical wound fluids were assembled in closed sterile collection bags, which were replaced daily with new sterile bags under aseptic conditions. Wound fluids were collected on POD-1 and once every 24 hours, until drain removal. The amount of fluids collected for each patient was carefully recorded each time.

\section{Seroma}

All patients were monitored by clinical exams and ultrasounds on POD 15, 20, 40 and 60 to detect liquid formation in the subcutaneous space and to determinate its dimension by volume measurements. Further investigations were performed based on patient clinical conditions. Patients were supposed to have seroma if symptomatic or in presence of more than $30 \mathrm{ml}$ of liquid in the subcutaneous space.

\section{Statistical Analysis}

All statistical analyses were performed using a statistical program (Graph Pad Instat Version 3.06 for Windows). Categorical variables were given as number and percentage. $\chi^{2}$ test was used to compare these latter. Continuous variable were given as mean and standard deviation. Unpaired $t$ test with Welch correction was used to compare data from the two groups of variables. The analysis of variance was performed with ANOVA with Bonferroni correction. A $p$ value $<0,05$ was considered statistically significant.

Table 1. Demographic and clinical features of patients. The difference between the two groups was not significant

\begin{tabular}{|c|c|c|c|}
\hline & Group FG & Group C & p values \\
\hline Gender & & & \\
\hline Male/Female) & $16 / 9$ & $15 / 10$ & n.s. \\
\hline Age (years) & & & \\
\hline mean \pm SD & $55.3 \pm 19.7$ & $48.1 \pm 15.2$ & n.s. \\
\hline $\mathrm{BMI}\left(\mathrm{Kg} / \mathrm{m}^{2}\right)$ & & & \\
\hline mean \pm SD & $28.2 \pm 14$ & $30 \pm 9.3$ & n.s. \\
\hline ASA Score Number & & & \\
\hline$|-| \mid$ & 10 & 9 & n.s. \\
\hline III-IV & 15 & 16 & n.s. \\
\hline $\begin{array}{l}\text { Previous abdominal operations } \\
\text { mean } \pm \text { SD }\end{array}$ & $1.5 \pm 1.1$ & $1.2 \pm 0.8$ & n.s. \\
\hline $\begin{array}{l}\text { Tickness of subcutaneous tissue }(\mathrm{cm}) \\
\text { mean } \pm \text { SD }\end{array}$ & $4.2 \pm 3.5$ & $3.8 \pm 2.8$ & n.s. \\
\hline $\begin{array}{l}\text { Subcutaneous space }\left(\mathrm{cm}^{2}\right) \\
\text { mean } \pm \text { SD }\end{array}$ & $120.9 \pm 80.1$ & $110.3 \pm 85.1$ & n.s. \\
\hline Comorbidities Diabetes, COPD & $30 \%$ & $35 \%$ & n.s. \\
\hline $\begin{array}{l}\text { Intraoperative blood loss (ml) } \\
\text { mean } \pm \text { SD }\end{array}$ & $125 \pm 45$ & $125 \pm 45$ & n.s. \\
\hline $\begin{array}{l}\text { Previous drug assumption } \\
\text { Antiplatelet, anticoagulant }\end{array}$ & $25 \%$ & $25 \%$ & n.s. \\
\hline $\begin{array}{l}\text { Platelets }\left(150-45010^{3} / \mu \mathrm{l}\right) \\
\text { mean } \pm \text { SD }\end{array}$ & $350 \pm 85$ & $360 \pm 70$ & n.s. \\
\hline $\begin{array}{l}\text { Albumin level }(\mathrm{g} / \mathrm{dl}) \\
3.5-5 \mathrm{~g} / \mathrm{dl}\end{array}$ & $4.1 \pm 0.7$ & $4.2 \pm 0.6$ & n.s. \\
\hline $\begin{array}{l}\text { INR (therapeutic range) } \\
\text { mean } \pm \text { SD }\end{array}$ & $0.9 \pm 0.3$ & $0.9 \pm 0.4$ & n.s. \\
\hline
\end{tabular}




\section{Results}

Age, gender, ASA grade, body mass index (BMI), number of previous abdominal operations, thickness of subcutaneous tissue and subcutaneous space are shown in Table 1. All of the 50 patients had uncomplicated intraoperative and postoperative course.

\section{Post-operative Pain}

Postoperative pain score values (Table 2) and analgesic consumption were higher in POD-1 and decreased during the following days. Pain values were ever lower in group FG, but they never reached statistical significance. Body temperature peaked at 24 hours and returned to almost same preoperative levels after 48 hours (data not shown).

\section{Drain Fluid}

Average amount of drain fluid collected in each patient is shown in Fig. 1. In both groups amount of fluid was more copious at POD-1. Initially, the fluid had blood characteristics, becoming serum-like afterward. Pattern of drain fluid production was similar in both groups decreasing significantly in the following days, although the amount of fluid was higher in group $\mathrm{C}$ at all times. These higher rates of secretion were statistically significant in POD $1,2,3(\mathrm{p}<0.01)$. Drain was removed when the amount of liquid over 24 hours was less than $30 \mathrm{ml}$. Drain was removed within POD 5 in $80 \%$ of FG group patients but only in $36 \%$ of $\mathrm{C}$ group patients $(\mathrm{p}<0.01)$ (Fig. 2). All drains were removed within POD 10.

Table 2. Postoperative pain according to VAS. Values are expressed a mean \pm standard deviation. The difference between the two groups was not significant

\begin{tabular}{lccc}
\hline & Group $\mathbf{F G}^{2}$ & Group $^{3}$ & p values \\
\hline $\mathrm{POD}^{1} 1$ & $4.1+2.8$ & $4.3+2.2$ & n.s. \\
\hline $\mathrm{POD} 2$ & $3.6 \pm 2.2$ & $4.1 \pm 1.9$ & n.s. \\
\hline $\mathrm{POD} 7$ & $2.3 \pm 2.4$ & $3.6 \pm 1.9$ & n.s. \\
\hline POD 15 & $1.9 \pm 1.7$ & $2.8 \pm 1.0$ & n.s. \\
\hline POD 30 & $0.9 \pm 0.8$ & $0.7 \pm 1.1$ & n.s. \\
\hline
\end{tabular}

POD. Post- Operative Day; ${ }^{2}$ Group FG. Group Fibrin Glue; ${ }^{3}$ Group C. Group Control

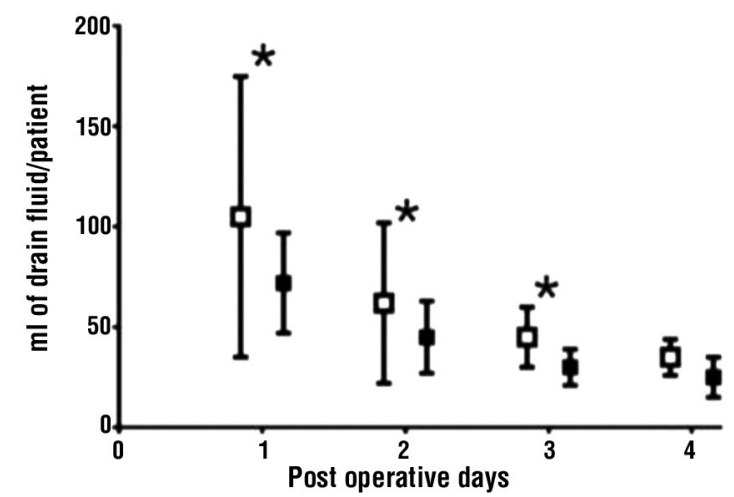

Figure 1. Drain fluid collected after surgery in the two group. White square, Group C; Black square, Group FG. Values are expressed a mean \pm standard deviation. Significant difference: ${ }^{*} p<0.01$

\section{Complications and Discharges}

No infective complication or bleeding of surgical site was observed. Average hospital stay was of $5.5 \pm 2$ in group FG and of $7.1 \pm 1.5$ in group $\mathrm{C}$ $(p<0.01)$.

Seroma

Table 3 shows number of patients with an amount of liquid over $30 \mathrm{ml}$ detected by ultrasound in different moment.

On POD 15 it has been observed the greatest

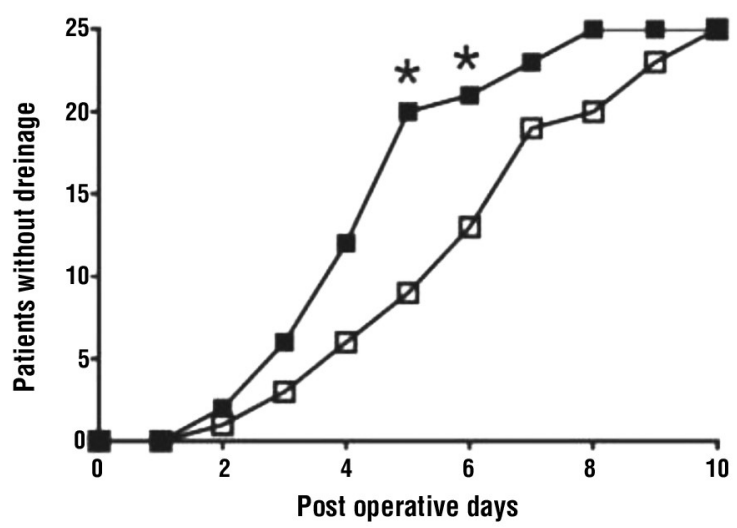

Figure 2. Drain removed in the two groups. White square, Group C; Black square, Group FG. Values are expressed as the number of patients without drainage on post-operative days. Significant difference: ${ }^{*} p<0.01$ 
Table 3. Number of patients with an amount of fluid greater than $30 \mathrm{ml}$ after surgery. At the ultrasound examination. The difference between the two groups was not significant

\begin{tabular}{lccccc}
\hline & Group FG2 & Group C3 & $\mathbf{p}$ values & & \\
\hline $\mathrm{POD}^{1}$ & $\mathrm{~N}^{\circ}$ & $\%$ & $\mathrm{~N}^{\circ}$ & $\%$ & n.s. \\
\hline 15 & 6 & 24 & 5 & 20 & n.s. \\
\hline 30 & 3 & 12 & 2 & 8 & n.s. \\
\hline 45 & - & - & 1 & 4 & n.s. \\
\hline 60 & - & - & - & - & n.s. \\
\hline
\end{tabular}

'POD. Post- Operative Day; ' 2 Group FG.Group Fibrin Glue; ${ }^{3}$ Group C. Group Control

number of patients with an amount of liquid over $30 \mathrm{ml}$, respectively in $24 \%$ of group FG patients and in $20 \%$ of group C patients ( $p$ value not significant). On POD 60 no patients showed an amount of liquid over $30 \mathrm{ml}$.

Seroma related symptoms were referred by 2 patients, one of $\mathrm{FG}$ group and one of $\mathrm{C}$ group. Six evacuating punctures were performed with resolution of clinical and ultrasound picture.

\section{Discussion}

This study shows that the spray instillation of fibrin glue with high concentration of thrombin in the subcutaneous space after sublayer incisional hernia repair reduces the amount of drained liquid and hospital stay without increasing surgical site complication. On the other hand formation of seroma was not significantly reduced.

The causes of seroma formation are still unclear. It seems that the thickness of the flap may lead to the hypertrophy of the lymphatic system along with a fluid accumulation in dead space derived from the surgical procedure. In addition, previous abdominal scars may serve as a mechanical barrier to the lymphatic system and retain extracellular fluids, thus contributing to seroma formation.

The incidence of seroma is largely variable from $2-30 \%$ (5). The large variability of seroma occurrence is specifically due to lack of consensus of its definition. Parker et al (14). define seroma as serous fluid that requires an evacuating puncture with reported incidence of $0.5 \%$. Other studies $(15,16)$ describe an incidence of seroma that persists beyond 2 months after the operation, presenting an incidence of 2.6 and $3.7 \%$, respectively. Chowbey et al (17). provide a seroma incidence of $33 \%$ based on the simple presence at palpation under clinical exploration.

The systematic use of ultrasounds is a noninvasive method that allows an accurate estimate of the amount of liquid collected in the subcutaneous space (18).

In our practice $(19,20)$, during open incisional hernia repair, we always place suction drain, although its use is controversial. Otherwise, we believe, agreeing with (21), that drainage liquid characteristics might provide important information for understanding the genesis of seroma formation $(22,23)$.

Various procedures have been used to reduce the incidence of seroma: suction drainage, quilting sutures, application of talc and, more recently, human fibrin glue without univocal results.

FG is available for sale both with high and low thrombin concentration and it has been utilized both to fix the prosthesis and to pull together two uneven surfaces.

There are few available literature data on the prevention of subcutaneous seroma by employing FG with high thrombin concentration and results are often conflicting.

Bercial et al (24) compared the use of suction drains, quilting sutures and fibrin sealant with thrombin concentration of $800-1200 \mathrm{IU} / \mathrm{ml}$. They observed that seroma formation was significantly higher in the fibrin sealant group than in the other two groups.

Toman et al (25), by comparing the effects of fibrin glue with low and high thrombin concentration (4 UI/ml Vs $500 \mathrm{UI} / \mathrm{ml}$ ), demonstrated that low-concentration fibrin glue had a protective effect on seroma formation with lower amounts of post-operative drainage.

In the field of incisional hernia repair with on lay mesh using fibrin sealant with high thrombin concentration, Chevrel et al (26) reported an increased rate of seroma formation, whereas Kingsnorth et al (27) noticed the opposite. Lee et al (28) observed a significant reduced rate of seroma formation after postbariatric abdominoplasty using fibrin glue at 
high thrombin concentration. Fernandez et al (29) pointed out that the application of highly concentrated fibrin sealant in incisional hernia repair with sub lay mesh and dermolipectomy reduce local morbidity with less wound care and shorter mean length of hospital stay. Azoury et al (30), in a recent large retrospective study of patients undergoing abdominal wall hernia repair, observed that the application of fibrin sealant do not reduce the formation of seroma.

In our study $4 \mathrm{ml}$ of FG with high concentration of thrombin have been applied over an area of more than $200 \mathrm{~cm} 2$, with the purpose of sealing microvascular injuries on uneven surfaces of subcutaneous and fascia; in fact no method was used to facilitate the adhesion of the uneven surfaces. The significant reduction of the amount of drained liquid could be due to the microvascular injuries sealing.

A subcutaneous collection of more than 30 $\mathrm{ml}$ was observed on POD 15 in 6 patients of group $\mathrm{FC}$ and in 5 patients of group $\mathrm{C}$; the placement of a US-guided drainage was required just for 2 patients. In all other cases liquid reabsorbed.

In our experience (31), the routinely use of fibrin spray glue leads apparently to an initial increase in costs of the surgical tools $(4 \mathrm{ml}$ prefilled set $=€ 179.58,10 \mathrm{ml}$ prefilled set $=$ $€ 457.35,1$ Easyspray kit $=€ 3.00$ vs 1 aspiration drainage $=€ 5.00,1$ non-absorbable suture $=€ 2.50$ ), but it also brings to a statistically significant reduction of hospitalization rates (on average, 20 hours less), post operative pain, medication costs ( $€ 205.00 /$ day in group B vs $€$ 250.00 / day in group A) and meals (€ 35.00 / day).

\section{Conclusions}

In conclusion, we need further studies to clarify the mechanism underlying seroma formation, but high thrombin fibrin sealant seems to be valid approach to reduce the collection of fluid in the subcutaneous space of patients undergoing incisional hernia repair with sub lay mesh.

\section{Funding}

No financial support has been obtained in the preparation of this study.

\section{Disclosure And Competing Interest}

The Authors report no conflict of interest in this work. The Authors declare that they have no competing interests. This article has not been presented nor published elsewhere, and no financial support has been obtained in its preparation.

\section{Author's Contributions}

All authors contributed to the study. F. Famà, C. Scimé and Di Vita G. conceived, devised and designed the manuscript. G. Terranova, D. Calì and Corbo G. collected the case and iconography. D'Orazio B., S. Bonventre and Geraci G. wrote the manuscript and participated in the sequence alignment. Di Vita G., Geraci G. and B. Cudia. revised and approved the final manuscript and its conclusions.

\section{Consent Section}

Informed written consent was obtained from all individuals participants included in this study.

\section{Ethics Approval}

No need for ethic comitee approval.

\section{Availability of Data}

The datasets generated during and/or analysed during the current study are available from the corresponding author on reasonable request.

\section{References}

1. Patti R, Aiello P, Caruso AM, Cudia B, Di Vita G. The improvement of quality of life a indication for elective surgery in elderly patients with minimally symptomatic inguinal hernia. Ann Ital Chir 2014; 85:136-42

2. Patti R, Almasio PL, Buscemi S, Famà F, Craxì A, Di Vita G. Inguinal 
hernioplasty improves the quality of life in patients with cirrhosis Am J Surg 2008; 196:373-8

3. Demetrashvili Z, Pipia I, Loladze D, Metreveli T, Ekaladze E, Kenchadze $\mathrm{G}$ et al. Open retromuscular mesh repair versus onlay technique of incisional hernia: A randomized controlled trial. Int J Surg 2017;37: 65-70

4. Coratti F, Coratti A, Malatesti R, Varrone F, Testi W, Savelli V et al. Treatment of median incisional hernia. Laparoscopic vs. open surgery: meta-analysis. Ann Ital Chir 2014; 85:358-64.

5. Klink CD, Binnebösel M, Lucas AH, Schachtrupp A, Grommes J Conze $J$ et al. Do drainage liquid characteristics serve as predictors for seroma formation after incisional hernia repair? Hernia 2010 $14: 175-9$.

6. Susmallian S, Gewurtz G, Ezri T, Charuzi I. Seroma after laparoscopic repair of hernia with PTFE patch: is it really a complication? Hernia 2001; 5:139-41.

7. Gubitosi A, Ruggiero R, Docimo G, Esposito A. Fibrin sealant in general surgery. Personal experience and literary review. Ann Ital Chir 2014; 85:153-8.

8. Sözen S, Çetinkünar S, Emir S, Yazar FM. Comparing sutures and human fibrin glue for mesh fixation during open inguinal hernioplasty. Ann Ital Chir 2016; 87:252-6.

9. Siragusa G, Geraci G, Guzzino M, Modica G, Bazan P. Ventra hernia surgery. Minerva Chir 2000; 55:189-94.

10. Di Vita G, D'Agostino P, Patti R, Arcara M, Caruso G, Davì V et al Acute inflammatory response after inguinal and incisional hernia repair with implantation of polypropylene mesh of different size. Langenbecks Arch Surg 2005; 390:306-11.

11. Di Vita G, Patti R, D'Agostino P, Caruso G, Arcara M, Buscemi S et al. Cytokines and growth factors in wound drainage fluid from patients undergoing incisional hernia repair. Wound Repair Regen 2006; 14:259-64.

12. Di Vita G, Patti R, D'Agostino P, Ferlazzo V, Angileri M, Sieli G et al Modifications in the production of cytokines and growth factors in drainage fluids following mesh implantation after incisional hernia repair. Am J Surg 2006; 191:785-90.

13. Patti R, Caruso AM, Aiello P, Angelo GL, Buscemi S, Di Vita G Acute inflammatory response in the subcutaneous versus periprosthethic space after incisional hernia repair: an original article. BMC Surg 2014; 15:14:91.

14. Parker HH 3rd, Nottingham JM, Bynoe RP, Yost MJ.Laparoscopic repair of large incisional hernias. Am Surg 2002; 68:530-3.

15. Heniford BT, Park A, Ramshaw BJ, Voeller G. Laparoscopic ventral and incisional hernia repair in 407 patients. J Am Coll Surg 2000; 190:645-50

16. Eid GM, Prince JM, Mattar SG, Hamad G, Ikrammudin S, Schauer $P R$. Medium-term follow-up confirms the safety and durability of laparoscopic ventral hernia repair with PTFE. Surgery 2003; 134:599-603

17. Chowbey PK, Sharma A, Khullar R, Soni V, Baijal M. Laparoscopic ventral hernia repair with extraperitoenal mesh: surgical technique and early results. Surg Laparosc Endosc Percutan Tech 2003; 13:101-5

18. Stocchero IN. Ultrasound and seromas. Plast Reconstr Surg 1993; 91:198.

19. D’Orazio B, Sciumé C, Corbo G, Martorana G, Di Vita G, Geraci G. Incisional Ventral Hernia Repair in Patients With Cirrhosis And Ascites, Still A Surgical Challenge Nowadays. Niger J Clin Pract 2020. In press. Doi: 10.4103/njcp.njcp_284_20.

20. Di Vita G, Patti R, Vetri G, Macchiarella B, D'Agostino P, Caruso Get al. Production of cytokines at the operation site. G Chir 2005; 26:241-5

21. Klink CD, Binnebösel M, Lucas AH, Schachtrupp A, Grommes J, Conze $\mathrm{J}$ et al. Serum analyses for protein, albumin and IL-1-RA serve as reliable predictors for seroma formation after incisional hernia repair. Hernia 2011; 15:69-73

22. D’Orazio B., Almasio P.L., Corbo G., Patti R., Di Vita G., Geraci G. Umbilical hernioplasty in cirrhotic patients with ascites: a case control study. Annal. Ital. Chir. 2020; In press.

23. Di Vita G, Patti R, Sparacello M, Balistreri Cr, Candore G, Caruso C. Impact of different texture of polypro- pilene mesh on the inflammatory response. Int J Immunopathol Pharmacol 2008;21:207-14

24. Bercial ME, Sabino Neto M, Calil JA, Rossetto LA, Ferreria LM. Suction drains, quilting sutures, and fibrin sealant in the prevention of seroma formation in abdominoplasty: which is the best strategy? Aesthetic Plast Surg 2012; 36:370-3.

25. Toman N, Buschmann A, Muehlberger T. Fibrin sealant and seroma formation following abdominoplasty. Chirurg 2007; 78:531-5.

26. Chevrel JP. The treatment of large midline incisional hernias by "overcoat" plasty and prothesis. Nouv Presse Med 1979; 24:695-6

27. Kingsnorth AN, Shahid MK, Valliattu AJ, Hadden RA, Porter CS. Open onlay mesh repair for major abdominal wall hernias with selective use of components separation and fibrin sealant. World $\mathrm{J}$ Surg 2008; 32:26-30.

28. Lee JC, Teitelbaum J, Shajan JK, Naram A, Chao J. The effect of fibrin sealant on the prevention of seroma formation after postbariatric abdominoplasty. Can J Plast Surg 2012; 20:178- 80.

29. Fernández Lobato R, García Septiem J, Ortega Deballon P, Martín Lucas FJ, Ruíz de Adana JC, Limones Esteban M. Tissucol application in dermolipectomy and incisional hernia repair. Int Surg 2001; $86: 240-5$

30. Azoury SC, Rodriguez-Unda N, Soares KC, Hicks CW, Baltodano PA, Poruk KE et al. The effect of TISSEEL fibrin sealant on seroma formation following complex abdominal wall hernia repair: a single institutional review and derived cost analysis. Hernia 2015;19:935-42

31. Geraci G, D'Orazio B, Chiarenza S, Agrusa A, Salamone G, Buscemi $S$, Di Buono G, Gulotta G. Efficacy of fibrin sealant in thyroid surgery. Is drainage still necessary? Ann Ital Chir 2019;90:100-5. 